\title{
Induction of seed coat darkening in common beans (Phaseolus vulgaris L.) and the association with cooking time after storage
}

\author{
Renata C. Alvares ${ }^{1}$, Helton S. Pereira ${ }^{2}$, Leonardo C. Melo ${ }^{2}$, Phillip N. Miklas ${ }^{3}$, Patrícia G. S. Melo ${ }^{4 *}$ \\ ${ }^{1}$ Empresa Caraíba, Rodovia GO-174, Km 4,9, S/N-Fazenda Lagoinha, Rio Verde, GO, Brazil \\ ${ }^{2}$ Embrapa Arroz e Feijão, Rodovia GO-462, km 12, Santo Antônio de Goiás, GO, 75375-000, Brazil \\ ${ }^{3}$ USDA-ARS Research Geneticist. USDA-ARS 24106 N Bunn Rd. Prosser, WA 99350-8694 USA \\ ${ }^{4}$ Universidade Federal de Goiás, Rodovia GO-462, km 0, Campus Samambaia, Goiânia, GO, 74001-970, Brazil
}

*Corresponding author: pgsantos@gmail.com

\section{Abstract}

Carioca is the most important edible dry bean (Phaseolus vulgaris L.) grown in Brazil. It represents the largest dry bean market class in the world. The seed coat of carioca beans will darken under adverse harvest conditions and with the increasing of storage time. In general, darkened seeds are associated with older seeds that suffer from prolonged cooking times. A relatively new 'slow darkening' trait is available in carioca that delays seed coat darkening under storage. However, its effect on cooking time is unknown. The objective of this work was to evaluate two induction methods of seed coat darkening and to examine the effect of slow darkening trait on cooking time after storage. Lines derived from four segregating populations resulting from crossings between cultivar BRSMG Madrepérola with slow seed coat darkening, and the parents BRS Estilo, BRS Cometa, BRS Notável and BRS Sublime with normal darkening were evaluated. An experiment inlcuding 220 lines, 55 per population and the five parents, in a $15 \times 15$ triple lattice was conducted in the winter growing season in Brasilia. Seed coat darkening and cooking time traits were evaluated. Two methods for inducing seed coat darkening were compared: an accelerated aging test using UV light for 72 hours, and an extended storage for 90 days under ambient conditions. The correlation between the induction methods ranged from 0.77 to 0.85 for the different populations indicating either method could be used to discriminate lines with normal versus slow darkening trait. The percentage of light-colored grain lines was identified by both induction methods of seed coat darkening ranged from 75 to $85.7 \%$ in the populations. The genetic correlation between seed coat darkening and cooking time varied from -0.06 to 0.48 , indicating that in some populations there is no significant genetic correlation between seed coat darkening and cooking time. Thus, light colored grains are not indicative of low cooking time, when they are considered genotypes with genetic variation for the seed coat darkening.

Keywords: accelerated darkening, extended darkening, genetic correlation, slow grain darkening.

Abbreviations: UV light - ultraviolet light; ED - extended darkening; CT - Cooking time; $\mathrm{Cl}$ - coincidence index; SD - slow darkening; ND - normal darkening; AD - accelerated darkening

Introduction

The seed (syn. grain) appearance (color, shape, and size) of dry edible beans is very important aspect of the commercialization process. In Brazil, consumer preference is differentiated by region mainly by seed color. By far, Carioca is the most popular dry bean market class in Brazil occupying $70 \%$ of consumer demand (Del Peloso and Melo, 2005). The carioca market type is defined by a seed coat with a light cream colored tegument with beige streaks. However, carioca beans will darken easily under delayed harvest conditions or with increasing time in storage (Junk-Knievel et al., 2007; Couto et al., 2010). Pinto bean which is a major market class in Mexico and the United States similarly suffers from seed coat darkening (Junk-Knievel et al., 2007). The environmental, biochemical and genetic factors affect seed coat darkening. Environmental factors include temperature, humidity, and luminosity conditions during harvest and while in storage (Couto et al., 2010). High levels of polyphenols (tannins) in the seed coat may be associated with increased darkening (Junk-Knievel et al., 2007; Silva et al., 2008). A few carioca cultivars exhibit slower darkening of the seed coat. Among them is BRSMG Madrepérola, which maintains a light cream coloration of the seed coat even after long storage periods (Silva et al., 2008, 2014; Carneiro et al., 2012; Baptista, 2016). Inheritance of the slow seed coat darkening trait in BRSMG Madrepérola varies from a single recessive gene to a few genes depending on the population and environment (Caneiro et al., 2012). This similar slow darkening trait in pinto bean is conditioned by a single recessive gene 's $s$ ' (Junk-Knievel et al., 2008; Islam et al., 2017).

Fast and reliable techniques have been developed recently for detecting the slow darkening trait (Junk-Knievel et al., 
2007). The accelerated aging method uses ultraviolet light to distinguish between slow and fast darkening lines in as little as three days. Extended storage method allows for gradual monitoring of the color changes of the seed coat, as well as the differentiation of the intensity between the evaluated genotypes.

Breeding programs are now concerned with characterizing any affects that the slow darkening seed coat trait may have on other traits, such as reduced cooking time (Carbonell et al., 2003; Alvares et al., 2016). On the other hands, consumer demand is for faster cooking beans (Corte et al., 2003; Ribeiro et al., 2013). Cooking time of beans is influenced by genetic and environmental factors. The interaction between $\mathrm{G} \times \mathrm{E}$ makes it difficult to select for faster cooking breeding lines (Carbonell et al., 2003; Corte et al., 2003; Rodrigues et al., 2005; Ribeiro et al., 2007; Bertoldo et al., 2009; Perina et al., 2014; Silva et al., 2014; Chiorato et al., 2015). Many studies have shown that cooking time increases with increased storage (Brackmann et al., 2002; Baldoni and Santos, 2005; Ribeiro et al., 2007, 2008; Morais et al., 2010). Moreover, beans with seed coat darkening are assumed to be older beans that will take longer to cook. The main question is: will the storage time have a similar effect on cooking time of beans which do differ in darkening? Our objective was to determine the effect of storage on cooking time of slow darkening carioca beans. We also evaluated two methods for inducing seed coat darkening of carioca beans.

\section{Results and discussion}

\section{Induction methods of seed coat darkening}

Cultivar BRSMG Madrepérola exhibited slower seed coat darkening in the accelerated aging (Fig.1) and extended storage (Table 2) tests, as confirmed in previous studies (Silva et al., 2008; Carneiro et al., 2012; Silva et al., 2014, Baptista, 2016). Cultivar BRSMG Madrepérola displayed a visually lighter color pattern after accelerated darkening when compared to the other parents. Cultivars BRS Estilo, BRS Cometa, BRS Notável and BRS Sublime presented darker coloration after the aging test and were classified as normal darkening. Junk-Knievel et al. (2007) reported that this distinction is consistent over locations and years, and does not alter seed germination. Thus, the selection of light grain genotypes using the accelerated aging method can be used to expedite breeding for the slow darkening trait, bypassing the need for extended storage to phenotype the trait.

The cultivars BRS Estilo and BRS Sublime had intermediate seed coat darkening, and BRS Notável and BRS Cometa exhibited the darkest seed coats under extended storage (90 ED) (Table 2). The population BRSMG Madrepérola $x$ BRS Sublime exhibited slower seed coat darkening, followed by BRSMG Madrepérola $x$ BRS Notável population at 90 ED. This range for cultivar and population means indicates the extended storage tests for detecting additional genetic variability and making gains from selection for the slow darkening trait in Carioca beans.

Highly significant phenotypic correlations (Table 3) were obtained for the seed coat darkening assessments between the accelerated aging and extended storage (90 ED) tests, considering the lines of each population separately, which ranged from 0.77 (BRSMG Madrepérola x BRs Estilo) to 0.85 (BRSMG Madrepérola x BRS Cometa). Further analysis showed the best agreement for classification of slow vs. regular darkening lines by both methods in BRSMG Madrepérola x BRS Estilo population, with a coincidence of $85.7 \%$. The lowest coincidence which was observed in the BRSMG Madrepérola $x$ BRS Sublime population (75\%) was still high (Table 4). These results confirm good agreement for seed coat classification between methods, suggesting the accelerated aging test will be useful for routine selection of slow darkening lines in a breeding program.

It should be stressed that the use of the ultraviolet light chamber provides faster results when compared to extended storage induced darkening. Moreover, it has the advantage of not harming seed germination (Junk-Knievel et al., 2007), making selection for the slow seed coat darkening trait possible at the plant level. However, each method should be used in accordance with the needs of the breeding program, given extended storage is able to detect greater variability for the trait than the accelerated aging test.

\section{Slow darkening and cooking time}

A primary goal of this project was to determine if the slow darkening trait affected cooking time, a trait shown to be variable in previous studies (Carbonell et al., 2003; Corte et al., 2003; Baldoni and Santos, 2005; Bertoldo et al., 2009; Ribeiro et al., 2013). Two populations were evaluated for cooking time. No significant differences were observed for the BRSMG Madrepérola $x$ BRS Estilo population for cooking time after extended storage for $90 \mathrm{~d}$. However, after $180 \mathrm{~d}$ of storage, there was a significant difference $(P<0.01)$. There were significant differences detected for cooking time among lines in the BRSMG Madrepérola $x$ BRS Cometa population for both 90 and $180(P<0.05)$ days of extended storage (Table 5). Of the two populations, BRSMG Madrepérola x BRS Cometa averaged shorter cooking times for both 90 and $180 \mathrm{~d}$ storage periods (Table 6). Conversely, Silva et al. (2014) observed the opposite, whereas BRSMG Madrepérola $\times$ BRS Estilo population had a shorter cooking time (29.3 $\mathrm{min}$ ) than the BRSMG Madrepérola $\times$ BRS Cometa population (33.6 $\mathrm{min}$ ) when evaluating grains stored for 190 days after harvest. Interestingly, the lines overall averaged less cooking time than the parental averages. Moreover, it is evidient that cooking time increased with increasing storage time, corroborating results from many studies (Brackmann et al., 2002; Baldoni and Santos, 2005; Ribeiro et al., 2007, 2008; Morais et al., 2010; Arrudda et al., 2012; Siqueira et al., 2014). Possible factors increasing cooking time of stored beans can be the action of polyphenols, by means of their polymerization in the tegument, or by lignification within the cotyledons, which in turn, inhibits water penetration and the hydration capacity of the grains (Moura, 1998).

Regarding the performance of the parents, BRSMG Madrepérola and BRS Estilo presented the lowest values for cooking time in the evaluations, remaining grouped by the means of the comparison test at 90 and 180 days after harvest (Table 6). Cultivar BRS Cometa showed the worst performance, presenting a mean of 36 minutes.

We examined phenotypic, genetic and environmental correlations between cooking time for seeds stored 90 after 
Table 1. Characteristics of the parents used in the obtain segregant populations.

\begin{tabular}{|c|c|c|c|}
\hline Genotype & $\begin{array}{l}\text { Maturity } \\
\text { Cycle }\end{array}$ & $\begin{array}{l}\text { Plant } \\
\text { Architecture }\end{array}$ & Genealogy \\
\hline BRSMG Madrepérola & Normal & prostrate & AN 512666-0/AN 730031 \\
\hline BRS Cometa & Semi-early & Upright & $\begin{array}{l}\text { A } 769 \text { /4/ EMP } 250 \text { /// A } 429 \text { / XAN } 252 \text { // C } \\
8025 \text { / G } 4449 \text { /// WAF } 2 \text { / A } 55 \text { // GN } 31 / \\
\text { XAN } 170\end{array}$ \\
\hline BRS Estilo & Normal & Upright & $\begin{array}{l}\text { EMP } 250 \text { /4/ A } 769 \text { /// A } 429 \text { / XAN } 252 \text { // V } \\
8025 \text { / PINTO VI } 114\end{array}$ \\
\hline BRS Notável & Semi-early & Upright & $\begin{array}{l}\text { A } 769 \text { /4/ A } 774 \text { /// A } 429 \text { / XAN } 252 \text { // V } 8025 \\
\text { / G 4449 /// WAF } 2 \text { / A55 // GN } 31 \text { /XAN } 170\end{array}$ \\
\hline CNFC Sublime & Normal & Upright & $\begin{array}{l}\text { EMP } 250 \text { / } 4 \text { / A } 769 \text { /// A } 429 \text { / XAN } 252 \text { // V } \\
8025 \text { / PINTO UI } 114\end{array}$ \\
\hline
\end{tabular}

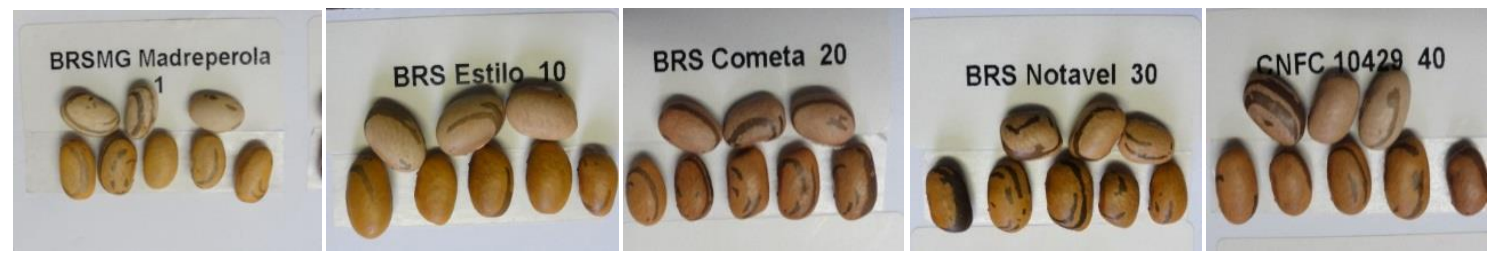

Fig 1. Common beans cultivar grains after 72 hours in grain accelerated darkening test (CNFC 10429 was the code used to identify cultivar BRS Sublime).

Table 2. Mean seed-coat darkening (rated 1 to 5) of parents and four segregating populations for seed harvested in Brasilia, 2012 winter crop, and stored for 90 days (90 ED).

\begin{tabular}{lc}
\hline Genotypes & Mean seed-coat darkening \\
\hline BRSMG Madrepérola & $1.1 \mathrm{~A}$ \\
BRS Estilo & $2.8 \mathrm{~B}$ \\
BRS Sublime & $2.7 \mathrm{~B}$ \\
BRS Cometa & $3.5 \mathrm{C}$ \\
BRS Notável & $4.2 \mathrm{D}$ \\
\hline Mean of the parents & 2.9 \\
\hline BRSMG Madrepérola x BRS Sublime & $2.7 \mathrm{a}$ \\
BRSMG Madrepérola x BRS Estilo & $3.0 \mathrm{C}$ \\
BRSMG Madrepérola x BRS Cometa & $3.0 \mathrm{C}$ \\
BRSMG Madrepérola x BRS Notável & $2.9 \mathrm{~b}$ \\
\hline Mean of the populations & 2.9 \\
\hline Means followed by the same letter (upper case and lower case letter) in the vertical do not differ from each other by the Scott \& Knott's test, at 5\% of probability.
\end{tabular}

Table 3. Pearson correlation coefficient estimates between seed-coat darkening scores from 90 day extended storage (90 ED) and the accelerated darkening UV light test for $72 \mathrm{~h}$ for four populations.

\begin{tabular}{lc}
\hline Genotypes & Correlation \\
\hline BRSMG Madrepérola x BRS Sublime & $0.78^{* *}$ \\
BRSMG Madrepérola x BRS Estilo & $0.77^{* *}$ \\
BRSMG Madrepérola x BRS Cometa & $0.85^{* *}$ \\
BRSMG Madrepérola x BRS Notável & $0.78^{* *}$ \\
\hline$*$ significant at 1\% of probability by test-t &
\end{tabular}

Table 4. Number of lines classified as slow (SD) and normal darkening (ND), according darkening method (accelerated - AD and extended-90 ED) for each population.

\begin{tabular}{|c|c|c|c|c|c|}
\hline \multirow{2}{*}{ Genotypes } & \multicolumn{2}{|c|}{ SD } & \multirow{2}{*}{$C(\%)^{1}$} & \multicolumn{2}{|c|}{ ND } \\
\hline & $A D$ & $90 \mathrm{ED}$ & & $A D$ & $90 \mathrm{ED}$ \\
\hline BRSMG Madrepérola x BRS Sublime & 14 & 16 & 75.0 & 41 & 39 \\
\hline BRSMG Madrepérola x BRS Estilo & 13 & 14 & 85.7 & 41 & 40 \\
\hline BRSMG Madrepérola x BRS Cometa & 24 & 21 & 83.3 & 29 & 34 \\
\hline BRSMG Madrepérola x BRS Notável & 22 & 19 & 77.3 & 33 & 37 \\
\hline Total across populations & 73 & 70 & 83.6 & 144 & 150 \\
\hline
\end{tabular}


Table 5. Summary of analysis of variance for cooking time of seeds for 90 and 180 days of extended storage (ED) for two populations grown in Brasilia, 2012 winter crop.

\begin{tabular}{|c|c|c|c|c|c|}
\hline \multirow[b]{2}{*}{ Source of variation } & \multirow[b]{2}{*}{ DF } & \multicolumn{2}{|c|}{$90 \mathrm{ED}$} & \multicolumn{2}{|c|}{$180 \mathrm{ED}$} \\
\hline & & MS & $\mathrm{P}$-value & MS & P-value \\
\hline Blocks & 1 & 182.00 & 0.003 & 269.50 & 0.001 \\
\hline Treatments & 111 & 28.00 & 0.023 & 49.77 & 0.000 \\
\hline Lines & 108 & 23.78 & 0.127 & 49.25 & 0.000 \\
\hline BRSMG Madrepérola x BRS Estilo & 53 & 17.33 & 0.649 & 46.66 & 0.002 \\
\hline BRSMG Madrepérola x BRS Cometa & 54 & 28.87 & 0.035 & 37.28 & 0.034 \\
\hline Between populations & 1 & 90.18 & 0.032 & 833.04 & 0.000 \\
\hline Parents & 2 & 70.15 & 0.029 & 80.95 & 0.041 \\
\hline Pops vs. Parents & 1 & 433.87 & 0.000 & 43.97 & 0.184 \\
\hline Error & 111 & 19.11 & & 24.59 & \\
\hline
\end{tabular}

$\mathrm{DF}=$ degrees of freedom, $\mathrm{MS}=$ mean squares

Table 6. Mean cooking time (minutes) at 90 and 180 of extended storage (ED) after harvest for two populations grown in Brasília, 2012 winter crop.

\begin{tabular}{|c|c|c|}
\hline Genotypes & $90 \mathrm{ED}$ & $180 \mathrm{ED}$ \\
\hline BRSMG Madrepérola & $24.2 \mathrm{~A}$ & $24.4 \mathrm{~A}$ \\
\hline BRS Estilo & $28.7 \mathrm{~A}$ & $27.3 \mathrm{~A}$ \\
\hline BRS Cometa & $36.1 \mathrm{~B}$ & $36.6 \mathrm{~B}$ \\
\hline Mean of the parents & 29.7 & 29.4 \\
\hline BRSMG Madrepérola x BRS Estilo & $21.6 \mathrm{~b}$ & $28.7 b$ \\
\hline BRSMG Madrepérola x BRS Cometa & $19.8 \mathrm{a}$ & $24.8 \mathrm{a}$ \\
\hline Mean of the populations & 20.7 & 26.8 \\
\hline CV (\%) & 21.1 & 18.5 \\
\hline Selective accuracy (SA) & 0.57 & 0.71 \\
\hline
\end{tabular}

Table 7. Estimates of the phenotypic, genetic and environmental correlation coefficients among cooking time (CT) in minutes at 90 and $180 \mathrm{~d}$ after harvest and seed coat darkening score at $90 \mathrm{~d}$ obtained with extended storage (ED) for two populations grown in Brasília, during the winter harvest.

\begin{tabular}{lcc}
\hline & \multicolumn{2}{c}{ Phenotypic correlation } \\
\cline { 2 - 3 } Genotype & CT 90 d/90 d score & CT 90 d/CT 180 d \\
\hline Population & -0.08 & $0.60^{* *}$ \\
BRSMG Madrepérola x BRS Estilo & 0.01 & $0.68^{* *}$ \\
BRSMG Madrepérola x BRS Cometa & -0.16 & $0.53^{* *}$ \\
Population & \multicolumn{2}{c}{ Genetic correlation } \\
BRSMG Madrepérola x BRS Estilo & -0.13 & $0.98^{* *}$ \\
BRSMG Madrepérola x BRS Cometa & -0.06 & $0.99^{* *}$ \\
& $-0.48^{*}$ & $0.97^{* *}$ \\
Population & \multicolumn{2}{c}{ Environmental correlation } \\
BRSMG Madrepérola x BRS Estilo & 0.01 & $0.31^{*}$ \\
BRSMG Madrepérola x BRS Cometa & 0.01 & $0.32^{*}$ \\
\cline { 2 - 3 }
\end{tabular}

*and "significant at 1 and $5 \%$ of probability, respectively by the Student's t-test.

harvest with the seed coat darkening scores (Table 7). Literature provides evidence that the cooking time is related to seed coat darkening. However, such conclusions are based on evaluations of genotypes that only show normal seed coat darkening. No significant phenotypic associations were found between CT90 and darkening (Table 7). Therefore, there is evidence that there is no relationship between the increase in cooking time and dark seed coat when slow-darkening lines are considered, nor that genotypes of light seed coat are indicative of low cooking time. The results also suggest that the selection should be practiced individually for each character since light grain is not an indicative of shorter cooking time. This finding disagrees with those reported in the literature (Brackmann et al., 2002; Baldoni and Santos, 2005; Coelho et al., 2009; Morais et al., 2010; Oliveira et al., 2011; Araújo et al., 2012).
Silva et al. (2014) also did not obtain any significant correlations between darkening and cooking time, concluding that the means for seed coat darkening do not reflect the behavior of the genotypes for a cooking time after grain storage. It is worth mentioning that the author also worked with slow-darkening populations. Oliveira et al. (2011) evaluated the quality of cooking of grains immediately after harvest and after six months of refrigerated storage at $0 \circ \mathrm{C}$. Their results showed that for Carioca grain genotypes, Pérola, Carioca and LH5, an increase in the darkening of the integument was observed, but only for the cultivar Pérola, a rise in the cooking time was noticed. These results corroborate with those obtained in this study, including Oliveira et al. (2011), who evaluated normal darkening genotypes. 
Araújo et al. (2012) obtained estimates of phenotypic, genetic and environmental correlation between darkening, cooking time, yield and tannin content in grains of population obtained from the crossing between BRSMG Madrepérola x RP-2 (normal-darkening line). The evaluations were performed at 30,60 and 90 days after harvest. The authors found significant and positive phenotypic correlation only between darkening and cooking time at 60 days postharvest (0.69). The other correlations between these two characters were not significant. Significant correlations were also obtained between darkening at 30,60 and 90 days after harvest and tannin content $(0.69,0.77$ and 0.83 , respectively).

The increase in cooking time was significantly correlated with grain storage time in the work of Siqueira et al. (2014) when evaluating five cultivars and one line of the Embrapa Arroz e Feijão breeding program for cooking time, coloring, hardness and lignin contents in six storage conditions. Among the cultivars evaluated, only cultivar BRSMG Madrepérola presented seed coat darkening. The authors also identified that the increases in cooking time with storage are independent of the grain lignification process. Another finding is that darkening and hardening occur during grain storage at different intensities in each genotype and there is not always a correlation between these variables. The cultivar BRSMG Madrepérola did not have its cooking time affected with storage. In contrast, BRS Pontal obtained additions in the cooking time, besides presenting dark seed coat.

All the phenotypic correlation estimates between cooking times for grains stored 90 and $180 \mathrm{~d}$ after harvest were positive, significant and of medium magnitude, suggesting that the selection for cooking time among lines can be practiced already at 90 days after harvest.

In the present study, the genetic correlations between darkening and cooking time were negative and of medium magnitude, corroborating with estimates of phenotypic correlation. Araújo et al. (2012) found a negative and low magnitude estimate between the cooking time at 90 days after harvest and seed coat darkening $(-0.11)$. However, the authors obtained a high and positive value between darkening and cooking time at 60 days after harvest (0.87), disagreeing with the results shown in this study.

A genetic correlation occurred between darkening and cooking for the BRSMG Madrepérola $x$ BRS Cometa population $(-0.48)$, indicating that the association between the two characters is inversely proportional, but of medium magnitude. The presence of negative correlations for the breeding is undesirable since the selection of low cooking time may cause undesirable changes for seed coat darkening. However, it is worth mentioning that although significant values had occurred, they were intermediate, indicating a small association.

The results indicate that when observing a cultivar that presents light seed coat even after a long period of storage, its cooking time cannot be inferred. This indicates that light seed coat are not indicative of low cooking time, nor that dark seed coat need more time for cooking. Increases in cooking time after storage have been reported to be associated with changes in grain proteins after storage, which may cause hardening of the integument and, consequently, longer time for its cooking (Rios et al., 2003).
Araújo et al. (2012) reported that slow-darkening seed coat presents smaller amount of tannins and require less time for cooking. The authors obtained positive and high correlation values between tannin content and seed coat darkening, suggesting that the increase in cooking time can be attributed to the increase in the content of tannin.

As a result, the consumer's habit of searching for light-seed coat beans in the market does not necessarily imply in a shorter cooking time in the pan, since no positive and significant correlation between cooking time and seed coat darkening has been identified. This result agrees with that of Siqueira et al. (2014), according to whom the tegument coloration in Carioca beans is not an appropriate parameter to predict the cooking time of the beans, as it has been used by traders and consumers.

All the phenotypic correlation estimates between cooking times for grains stored 90 and $180 \mathrm{~d}$ after harvest were positive, significant and of medium magnitude, suggesting that the selection for cooking time among lines can be practiced already at 90 days after harvest. Genetic correlations between cooking times were positive and close to the unit, as expected (Table 7). A positive environmental correlation was found between CT90 and CT 180 for populations and for BRSMG Madrepérola $x$ BRS Estilo. The presence of this type of correlation indicates that the variation in the environmental factors affected the cooking time of the lines of this population in the same direction. Therefore, the unfavorable environmental conditions that negatively affect the cooking of grains, the seed coat darkening will be directly influenced, producing darker seed coat. However, Araújo et al. (2012) did not find a significant environmental correlation for cooking time and grain darkning of $\mathrm{F}_{2: 3}$ progenies.

In $100 \%$ of the evaluated pairs of characters, genetic correlations were equal to or greater than phenotypic correlations, an extremely interesting fact, since genetic correlations have a greater practical effect on works of plant breeding. In $100 \%$ of the cases, estimates of phenotypic and genetic correlation were higher than the environmental correlations. Although one undesirable correlation had been significant, it did not form a complete association, being possible to obtain recombinants that are promising for both characters.

\section{Materials and Methods}

\section{Genetic material, plant grown and experimental design}

Four segregating populations were generated by crossing the slow seed coat darkening parent BRSMG Madrepérola (Carneiro et al., 2012) with four normal seed coat darkening parents: cultivars BRS Estilo (Melo et al., 2010), BRS Cometa (Faria et al., 2008), BRS Notável (Pereira et al., 2012) and BRS Sublime (Table 1). The parents BRS Estilo and BRS Cometa were chosen because they exhibit short and long cooking times, respectfully.

These populations were advanced in bulk to the $F_{5}$ generation and $55 F_{5: 6}$ lines were randomly selected and multiplied as $F_{5: 7}$ lines for evaluation with the five parents in a $15 \times 15$ triple lattice design with three replications. Plots consisted of two $3-\mathrm{m}$ rows with $0.45 \mathrm{~m}$ row spacing. The field experiment was conducted in the winter growing season in Brasília, DF, Brazil (15046'47"S, 47055'47"W and 
$1171 \mathrm{~m}$ altitude). Fertility, irrigation, and cultivation were managed for optimal production.

The seed harvested from all plots were evaluated for seed coat darkening. But only the lines derived from the BRSMG Madrepérola x BRS Estilo and BRSMG Madrepérola x BRS Cometa populations and respective parents were evaluated for cooking time.

\section{Comparison of induction methods}

The seeds of lines were subjected to extended and accelerated post-harvest darkening methods. The extended darkening (ED) method consisted of placing seeds in transparent plastic bags and then storing them for 90 days (90 ED) under ambient environmental conditions (temperature $-24 / 28^{\circ} \mathrm{C}$ and humidity $40 / 80 \%$ ). The level of seed coat darkening for this method was rated from 1 (very light seed coat) to 5 (very dark seed coat) (Silva et al., 2008). A line was considered to be slow darkening if its score averaged less than 2.5 .

The accelerated aging method followed the procedure by Junk-Knievel et al. (2007), whereby seeds were exposed to ultraviolet light, which simulates extended storage (JunkKnievel et al., 2007; Elsadr et al., 2011; Felicetti et al., 2012). The seeds were placed in petri dishes and exposed to ultraviolet light in an enclosed light chamber for 72 hours. Seeds that showed an evident darkening of the seed coat were classified as normal darkening, and those that presented a slight darkening of the seed coat were classified as slow darkening. For this method, lines were scored either 1 for slow darkening or 2 for normal darkening.

Cooking time was evaluated for a portion of the seeds that were subjected to the extended 90 day storage test (90 ED) and a remaining portion that was stored for 180 days ( 180 ED) after harvest. Cooking time was evaluated at 90 and 180 days after harvest because these storage times represent realistic elapsed times between harvest and product placement on supermarket shelves. Often growers or dealers will delay sale of their product in an attempt to achieve higher prices. Cooking time (CT) was measured in minutes using the Mattson Cooker based on the method of Proctor and Watts (1987). Whole seeds were soaked in 100 $\mathrm{ml}$ of distilled water for $16 \mathrm{~h}$ at room temperature. Twentyfive randomly chosen seeds were placed in the Mattson Cooker which fit inside a glass beaker containing $1,000 \mathrm{ml}$ of boiling water. The cooker is composed of 25 rods, with each grain individualized in a cavity of the apparatus, supported perpendicularly to a metal rod of 90 grams and with $1.0 \mathrm{~mm}$ of tip diameter. The time was recorded, in minutes, until the $13^{\text {th }}$ rod of the cooker penetrated a cooked seed. A 60 minute time limit was set for cooking the samples.

\section{Statistical and genetics analyzes}

Analysis of variance was conducted for seed coat darkening at 90 ED for all four populations, and for cooking times at 90 ED and 180 ED for the two populations and their parents. Blocks and treatment were considered random effects. Mean comparisons were based on Scott-Knott's test ( $p$-value $\leq 0.05$ ). The phenotypic, genetic and environmental correlation coefficients between the seed coat darkening obtained were estimated with extended storage at 90 days after harvest, and seed coat at СT90 with CT180. As a measure of the informative qualification of the experiments, the selective accuracy (SA) was calculated, as proposed by Resende and Duarte (2007), who considered the F-test values of the analysis of variance.

Pearson's simple linear correlation coefficient (Steel and Torrie, 1980) was used to compare seed coat darkening for the extended storage (90 ED) and accelerated aging tests. The coincidence index $(\mathrm{CI})$, which represents the percentage of lines were identified as slow darkening by both methods. Genes software (Cruz et al., 2013) was used to conduct the statistical analyses.

\section{Conclusions}

Accelerated and extended darkening induction methods allowed discriminating lines that have slow and normal seed coat darkening according to the need. No significant genetic correlation between darkening and cooking time of seed coat was found. Therefore, light seed coat is not indicative of a low cooking time when genotypes with genetic variation for seed coat darkening are considered.

\section{References}

Alvares RC, Silva FC, Melo LC, Melo PGS, Pereira HS (2016) Estimation of genetic parameters and selection of high-yielding, upright common bean lines with slow seed-coat darkening. Genet Mol Res. 15:1-10.

Araújo LCA, Ramalho MAP, Abreu AFB (2012) Estimates of genetic parameters of late seed-coat darkening of carioca type dry beans. Cienc Agrotec. 36:156-162.

Baldoni B A, Santos JB (2005) Capacidade de cozimento de grãos de famílias de feijão do cruzamento Esal 693 X Rosinha. Acta Sci-Agron. 27:233-236.

Baptista JEC (2016) Qualidade tecnológica de grãos de feijão Carioca armazenados. Dissertação (Mestrado em Fitotecnia). Universidade Federal de Lavras, 150p.

Bertoldo JG, Coimbra JLM, Barili LD, Vale NM, Rocha F (2009) Correlação entre caracteres de produção e tempo de cocção em feijão em dois ambientes. Rev Cienc Agron. 40:135-140.

Brackmann A, Neuwald DA, Ribeiro ND, Freitas ST (2002) Conservação de três genótipos de feijão (Phaseolus vulgaris I.) do grupo carioca em armazenamento refrigerado e em atmosfera controlada. Cienc Rural. 32:911-915.

Carbonell SAM, Carvalho CRL, Pereira VR (2003) Qualidade tecnológica de grãos de genótipos de feijoeiro cultivados em diferentes ambientes. Bragantia. 62:369-379.

Carneiro JES, Abreu AFB, Ramalho MAP, Paula Junior TJ, Del Peloso MJ, Melo LC, Pereira HS, Pereira Filho IA, Martins $M$, Vieira RF, Martins FAD, Coelho MAO, Carneiro PCS, Moreira JAA, Santos JB, Faria LC, Costa JGC, Teixeira H (2012) BRSMG Madrepérola: Common bean cultivar with late-darkening Carioca grain. Crop Breed Appl Biot. 4: 281284.

Chiorato AF, Carbonell SAM, Bosetti F, Sasseron GR, Lopes RLT, Azevedo CVG (2015) Common ean genotypes for agronomic and marker-related traits in VCU trials. Sci Agr. 72:34-40.

Coelho SRM, Preudencio SH, Nóbrega LHP, Leite CFR (2009) Alterações no tempo de cozimento e textura dos grãos de 
feijão comum durante o armazenamento. Cienc Agrotec. 33:539-544.

Corte AD, Moda-Cirino V, Scholz MBS, Destro D (2003) Environment effect on grain quality in early common bean cultivars and lines. Crop Breed Appl Biot. 3:193-202.

Couto KR, Santos JB, Ramalho MAP, Silva GS (2010) Identificação de marcadores moleculares microssatélites relacionados ao escurecimento de grãos em feijão. Pesq Agropecu Bras. 45:1268-1274.

Cruz CD (2013) Genes - A software package for analysis in experimental statistics and quantitative genetics. Acta SciAgron. 35:271-276.

Del Peloso MJ, Melo LC (2005) Potencial de rendimento da cultura do feijoeiro-comum. Embrapa Arroz e Feijão.131p.

Elsadr HT,.Wright LC, Pauls KP, Bett KE (2011) Characterization of seed coat post-harvest darkening in common bean (Phaseolus vulgaris L.). Theor Appl Genet. 123:1467-1472.

Faria LC, Del Peloso MJ, Melo LC, Costa JGC, Rava CA, Díaz JLC, Faria JC, Silva H T, Sartorato A, Bassinelo PC, Trovo BF (2008). BRS Cometa: a carioca common bean cultivar with erect growth habit. Crop Breed Appl Biot. 2:167-169.

Felicetti E, Song Q, Jia G, Cregan P, Bett KE, Miklas PN (2012) Simple sequence repeats linked with slow darkening trait in Pinto Bean discovered by single nucleotide polymorphism assay and whole genome sequencing. Crop Sci. 52:1600-1608.

Islam NS, Marsolais F, Dhaubhadel S (2017) Identification and characterization of slow darkening gene in pinto bean (Phaseolus vulgaris L.). In: Biennial Bean Improvement Cooperative Meeting, 2017, East Lansing.

Junk-Knievel DC, Vandenberg A, Bett K (2007) An accelerated post-harvested seed coat darkening protocol for pinto beans grown across different environments. Crop Sci. 47:694-702.

Junk-Knievel DC, Vanderberg A, Bett KE (2008) Slow darkening in pinto bean (Phaseolus Vulgaris L.) seed coats is controlled by a single major gene. Crop Sci. 48:189-193.

Melo LC, Del Peloso MJ, Pereira HS, Faria LC, Costa JGC, Díaz JLC, Rava CA, Wendland A, Abreu AFB (2010) BRS Estilo Common bean cultivar with carioca grain, upright growth and high yield potential. Crop Breed Appl Biot. 10:377-379.

Morais PPP, Valentini G, Guidolin AF, Baldissera JNC, Coimbra JLM (2010) Influência do período e das condições de armazenamento de feijão no tempo de cocção. Rev Cienc Agron. 41:593-598.

Moura ACC (1998) Análises físico-químicas e enzimáticas antes e após armazenamento em grãos de feijão (Phaseolus vulgaris I.) submetidos a diferentes tempos e tipos de secagem. Dissertação (Mestrado em Fitotecnia) Universidade Federal de Lavras, Lavras, 70p.

Oliveira VR, Ribeiro ND, Mazieiro SM, Cargnelutti Filho A, Jost E (2011) Qualidade para o cozimento e composição nutricional de genótipos de feijão com e sem armazenamento sob refrigeração. Cienc Rural. 41:746-752.

Pereira HS, Wendland A, Melo LC, Del Peloso MJ, Faria LC, Costa JGC, Nascente AS, Díaz JLC, Carvalho HWL, Almeida VM, Melo CLP, Costa AF, Posse SCP, Souza JF, Abreu AFB, Magaldi MCS, Guimarães CM, Oliveira JP (2012) BRS Notável: A medium-early-maturing, disease-resistant carioca common bean cultivar with high yield potential. Crop Breed Appl Biot. 12:220-223.

Perina EF, Carvalho CRL, Chiorato AF, Lopes RLT, Gonçalves JGR, Carbonell SAM (2014) Technological quality of common bean grains obtained in different growing seasons. Bragantia. 73: 14-22.

Proctor JR, Watts BM (1987) Development of a modified mattson bean cooker procedure based on sensory panel cookability evaluation. Cana Inst F Sci Tec J. 20:9-14.

Resende MDV, Duarte JB (2007) Precisão e controle de qualidade em experimentos de avaliação de cultivares. Pesqui Agropecu Trop. 37:182-194.

Ribeiro ND, Rodrigues JA, Cargnelutti Filho A, Poersch NL, Trentin M, Rosa SS (2007) Efeitos de períodos de semeadura e das condições de armazenamento sobre grãos de feijão para o cozimento. Bragantia. 66:157-163.

Ribeiro ND, Poersch NL, Rosa SS (2008) Períodos de semeadura e condições de armazenamento na qualidade de cozimento de grãos de feijão. Cienc Rural. 38:936-941.

Ribeiro ND, Mambrin RB, Storck L, Prigol M, Nogueira CW (2013) Combined selection for grain yield, cooking quality and minerals in the common bean. Rev Cienc Agron. 44:869-877.

Rios AO, Abreu CMP, Corrêa AD (2003) Efeito da estocagem e das condições de colheita sobre algumas propriedades físicas, químicas e nutricionais de três cultivares de feijão (Phaseolus Vulgaris L.). Ciencia Tecnol Alime. 23:39-45.

Rodrigues JA, Ribeiro ND, Cargnelutti Filho A, Trentin M, Londero PMG (2005) Qualidade para o cozimento de grãos de feijão obtidos em diferentes épocas de semeadura. Bragantia. 64:369-376.

Silva GS, Abreu AFB, Silva FB (2008) Genetic control of early grain darkening of carioca common bean. Crop Breed Appl Biot. 8:299-304.

Silva FC, Melo PGS, Pereira HS, Melo LC (2014) Genetic control and estimation of genetic parameters for seedcoat darkening of carioca beans. Genet Mol Res. 13:64866496.

Siqueira BS, Pereira WP, Batista KA, Oomah BD, Fernandes $K F$, Bassinello PZ (2014) Influência of storage on darkening and hardening of slow-and regular-darkening carioca bean (Phaseolus Vulgaris L.) genotypes. J Agric Stud. 2:87-104.

Steel RGD, Torrie JH (1980) Principles and procedures of statistic: with special reference to the biological sciences. New York: Mc Graw-Hill. 632 p. 